\title{
POWER MAINTENANCE OF RELIGIOUS ELITES IN MINORITY TOURISM COMMUNITIES: TAKING HUI VILLAGES IN SANYA AS AN EXAMPLE ${ }^{1}$
}

\author{
HuANG KAIJIE, SUN JiUXIA² \\ SUN YAT-SEN UNIVERSITY
}

\begin{abstract}
Although cultural elites in China's ethnic minority communities are the main carriers and maintainers of traditional culture, changes in the power of their traditional authority has not been studied much relative to tourism development. This article explores the changes in community religious elites' authority with regard to conflicts concerning tourism development. The methods involved interviewing and observation in a Hui ethnic minority community in Fenghuang Town, Sanya Municipality of provincial Hainan Island. It has been found that tourism development strengthens the villagers' identity with religious authorities while reinforcing cultural elites' management powers in religious affairs. However, in conflicts of interest arising from tourism, the religious elites' powers have become "externally strong, yet internally weak" by eroding traditional authority, and personal competencies have become a foundation for applying secular mediation powers. The inherent flexibility and initiative of the religious elites' authority has resisted the weakening of their power brought by the modernity of tourism to some extent, and provides a reference for future studies on how to resolve the contradiction between modernization and the continuation of traditional culture.
\end{abstract}

1 This study was supported by a grant from the National Natural Science Foundation (No. 41171124) and by a grant from the National Social Science Foundation of China (No.15ZDB118).

${ }^{2}$ Address for correspondence: Center for Tourism Planning and Research, Sun Yat-Sen University, 329 Building, 135 Xingangxi Road, Guangzhou, 510275, P. R. China; Fax: +86020 84113621, E-mail: sjxia@21cn.com. 
Keywords: tourism development, Hui people in Sanya, community elites, religious elites, power change

\section{Introduction}

Community elites are persons in leadership positions who master competencies or resources beyond the reach of most of the local villagers, and have public influence and authority within a community (He, 2000; Jin, 2002). Depending on the type of resources mastered, they may be divided into political elites, economic elites, traditional cultural elites, etc. As an important type of community elite, traditional cultural elites are mostly persons who command local traditional cultural resources. Such individuals may be the main carriers and maintainers of local traditional culture, and include clan elders, religious leaders, senior community cultural scholars, folk artists, etc. Religious elites in this study are a type of traditional cultural elite. Relevant studies show that powers of the community elites adapt when an external force affects the social and cultural environment of a community (He, 2000; Fei 2012; Zang 2011). As an important impetus to modernization, tourism impacts institutional, spiritual, and cultural aspects of minority areas in the process of economic development ( $\mathrm{Wu}, 2006)$. The effect of tourism on minority communities has prompted longstanding controversies in the academic community. On the one hand, community participation in tourism can strengthen the villagers' cultural identity (Sun, 2004), activate some forgotten cultural traditions (Grunewald, 2002), and inspire the villagers to value and conserve local culture (Sun, 2005). On the other, though, tourism can be an important contributor to modernity that may also impact local traditional morals and customs, thereby resulting in the decline of local culture (Joeph, 2001; Liao, 2005). With the intrusion of tourism in minority areas, the social and cultural impacts are in need of deep exploration. As the most visible representatives of the minority culture, the traditional cultural elites are inevitably influenced. In addition, the traditional cultural elites shoulder the important responsibility of minority culture protection and inheritance, and are an important lens for studying tourism impacts on the traditional minority culture.

There are few studies on the effects of tourism on community elites, either in China and abroad. Some scholars have noticed that tourism development has promoted the rise of some local economic elites by intruding upon the formerly closed, fixed community economy, 
accelerating the generation of modern awareness among the villagers, and accelerating the free flow of capital (Cynthia, 1995; Wu, 2007; Zhu, 2012; Zhou, 2013; Liu, 2008). There are studies by Brohman (1996) and Tosun (2000) on the negative impacts, who think that community elites tend to manipulate community participation organizations for self-serving purposes. Walpole and Goodwin (2000) further point out that the local economic elites, offering services and facilities to tourists, encroach on the villagers' participation in the tourism economy and further expand the community income-disparities. Weng Shixiu and Peng Hua (2010) point out that the displacement of powers of the political elites in Furong Village on the Nanxi River in Zhejiang Province has created a structural barrier to the tourism development of this ancient village. These studies mainly capture the management and economic elites, while Zhang Xiaoming (2006) thinks that the studies of elites in community tourism participation must stress the importance of the social elites in the community power structure. In sum, there are two-way interactions between tourism development and community elites. On the one hand, the role-changes of the community elites in the context of tourism development reflect the local tourism impacts laterally, but currently such studies focus mainly on the impacts on the economic elites as a market-driven economic activity with few studies on the other types of elites. But on the other, the community elites also have corresponding impacts on tourism development, and the significance of the traditional cultural elites in local traditional culture and tourism development and the application of their powers during tourism development are noteworthy.

This article looks at the impacts of tourism development from the perspective of the power on, and of, the traditional cultural elites in minority communities. The two Muslim Hui villages of Huihui and Huixin in Fenghuang Town, Sanya Municipality of provincial Hainan Island, China are taken as examples. The authors conducted 10-day fieldwork in March 2014, with the focus on learning about events and conflicts arising from tourism development and interactions of powers of religious elites. The fieldwork was conducted mainly by means of interviews, where 39 persons were interviewed, including the religious elites of mosques, ordinary villagers, local government and village officials, and non-local Muslims.

Power is an abstract concept. Studies on powers are conducted on macroscopic and microscopic levels. On the microscopic level, it is seen in the process of roles that elites marshal to influence the objectives that reflect their wills and requirements. Foucault thinks that powers penetrate 
into microscopic social interactions, where each social subject may become a subject of power (Giddens, 2009). The observation of powers begins with how the elites wield power in operations and interactions involving conflicts (Giddens, 2009). In this study, we sought to explore how the powers of the traditional cultural elites have changed from the past, clarify the reasons for such changes, and understand how the traditional cultural elites influence tourism development of (their) minority communities. Huihui and Huixin Villages are the only villages largely inhabited by the Hui people in Hainan Province, with a total population of 7,838 at the end of 2012. The villages are adjacent to the "Edges of the Heaven" seaside resort area near Sanya Phoenix International Airport and the railway station, boasting an advantaged geographic location. Since the beginning of China's economic reform and loosened travel restrictions, the tourism economy has driven the Hui people in Sanya to deal extensively with commercial activities (Sun and Chen, 2011). Today, the per capita annual income of the two villages is about RMB 13,000 (USD 2,000; INR $133,000)$, much higher than that of the other villages in the town. ${ }^{3}$ The villagers follow Islam and maintain relatively complete traditional beliefs and customs. In daily life, the villagers speak the Huihui dialect and dress largely pursuant to Islamic rules. The women wear scarves on public occasions, the weddings and funerals completely follow Islamic rules, there are five daily worship sessions, and every Friday (Jumah), the villagers gather for collective worship at a mosque. There are six mosques in the two villages, which offer education to the villagers in Arabic and the Qur'an. Currently, the religious elites in the Hui communities are six prestigious and experienced mosque imams.

\section{Power Expansion and Enhancement of Religious Elites under the Influence of Tourism}

For the religious elites, religious affairs are the core area of daily power operations in the Hui villages. By observing the power of the traditional cultural elites in the context of tourism development, we can easily find the impacts of external forces on the local traditions.

\footnotetext{
${ }^{3}$ Quoted from The Beauty of Fenghuang, published by The town Government of Fenghuang, Sanya, 2012.
} 


\section{Expanded sphere of influence of powers}

The development of the International Tourism Island has led to the rapid development of the resort market of the Hui villages in Sanya. Every winter, large numbers of elderly Muslims from Qinghai, Gansu, Ningxia, etc., are enticed by the mild climate to swarm into the Hui villages for a wintering respite or for doing business (Sun and Zhang, 2015). The Hui villages in Sanya have received 100,000 non-local Muslims in recent years. They have established long-term close connections with the local mosques and religious elites, and they attend mosque worship and major local religious activities regularly. The religious elites also have religious influence on non-local Muslims; "Religious affairs here are the same as those out there, and affairs that should be handled by imams have to be handled by imams", (owner of a Lanzhou noodle restaurant B03). An imam in Huihui Village (A06) said, "Religious affairs of non-local Muslims here, including weddings and funerals, are handled pursuant to the religious customs by mosques." When a mosque needs to raise funds, the imam mobilizes non-local Muslims for donations. Non-local Muslims have also shown a strong religious identity with the community: "Every non-local Muslim here is very willing to donate money, because all Hui people in the world are a big family" (Wintering Muslim AO4). This is exemplified by the fact that nearly one-third of the donors for the ancient mosque reconstruction project, completed in 2013, were non-local Muslims.

The arrival of non-local Muslims has expanded the scope of power of the religious elites in the Hui villages in relation to religious affairs, and has expanded the ethnic boundary to religious boundary. As a mobile business, tourism has strengthened connections between the non-local Muslims and the local society, and expanded the foundation of powers of the religious elites.

\section{Enhanced strength of influence of powers}

The development of the tourism economy has affected the villages' religious images as individual villagers are prone to violate Islamic rules and doctrines. In this case, the traditional cultural elites in the Hui villages have become very active in exercising their powers to maintain the religious rules and to enhance their influence by seeking to strengthen the villagers' identification with the religious rules. 
Islamic rules prohibit Muslims from drinking alcoholic beverages and stipulate that no drinking vessel should be placed in the homes. However, since the 1990s, many local Hui seafood restaurants had catered to the tourist trade by offering liquor to tourists in order to remain competitive. In view of this, the imams and the other religious elites launched a public campaign to bring restauranteurs in line with Islamic doctrine and practice. At the beginning, the imams used the evening worship sessions and Jumah days to explain the hazards of smoking and drinking, but there was little effect upon the violators. Later, the religious elites, represented by the imams, made the appeal door-to-door and talked to the restaurant owners alone after mosque gatherings. If any villager still remained unpersuaded, an imam invited his/her relatives and friends to apply pressure on him/her. These measures have considerably restored the Hui villagers' practice of religious rules. Today, the restaurants in the two Hui villages no longer serve liquor to the tourists. 28 out of the 31 villagers interviewed explicitly prohibited their family members from drinking liquor. The owner of a fresh fish soup restaurant (A31) said, "Drinking and smoking are banned by imams and villagers here. What the imam says should be obeyed, because it complies with the Qur'an; otherwise one would be punished in the afterlife." Another villager (A12) said, "These rules teach us to get better; if you don't follow them, others would say that 'you're not good', so that you have no face in the village." The strong powers of the religious elites have been shown in their binding force in the tourism activities.

According to the locals, violations of the religious rules were prevalent during the early stage of China's economic reform and loosened travel restrictions, when many villagers smoked and drank alcohol. However, the imams rarely intervened at that time, but now the religious elites are very active in promoting the religious rules. After the worship session on each Thursday afternoon, the imams visit the village, checking cigarette and liquor consumption at the restaurants and reminding young people doing business outside to attend Jumah day activities punctually and not to gamble or fight. This never occurred in the past. Mr. Zhao at Nankai Mosque (A01) said, "We have to be active, because there are many more things to do today than in the past. If we do not act well, the image of the whole ethnic group or religion will be affected. In front of outsiders, we should show unity. Many foreign Muslims have visited our village, including the Prime Minister of Malaysia, and we should not humiliate our people." These changes have been brought about especially by increased foreign visitor exchanges arising from tourism development and increased awareness of the ethnic identity among the religious elites. 


\section{Enhancement and Erosion of Religious Elites' Public Mediation Powers in Tourism-Related Activities}

With the establishment of the Hainan International Tourism Island, tourism real estate development in Sanya Municipality has experienced a new upsurge. The Hui villages with advantaged locations have revealed this upsurge, accompanied by conflicts and disputes arising from land and real estate. Such events are public stages for studying operations of the power of the traditional cultural elites.

\section{Erosion of elites' mediation powers internal to communities}

As representatives of the traditional cultural elites, the powers of the Hui religious elites are evident not only in religious affairs but also in other public areas of the communities. In the past, the elites not only managed religious affairs but also used their powers in mediation capacity for handling internal disputes. For example, marital and neighborhood disputes were often mediated by the imams of mosques. However, though the religious elites also participate in the mediation of disputes over tourism development, outcomes are not as satisfactory.

A land dispute that occurred in March 2014 in Huihui Village is taken as an example here. The family of villager Chen $\mathrm{X}$ had two pieces of residential land, one big and one small. The big piece had been allocated to his eldest and middle sons for house construction, and the small piece was about to be allocated to his youngest son. The eldest son suddenly claimed that he owned part of the small piece of the housing land. Since Chen X had not yet applied for a land title certificate for his youngest son, the brothers stuck to their own views and made no concession. The imam of the West mosque then came for mediation, telling them the importance of fraternal care and family harmony, and persuading them to make concessions respectively. Even after more than an hour's mediation, the dispute had not been settled. Finally, based on the advice of the village committee, the brothers decided to refer the dispute to the court for judgment.

With the rise of the tourist accommodation business, every year there are many disputes among the villagers over land, real estate, etc. In Huihui Village alone, seven or eight disputes over real estate or land occurred in 2013. Among these disputes, half were settled by the village committee while the other half were settled by the town government or court. Since 
there are considerable economic interests behind the disputes, the religious elites can hardly exercise their influence in this regard.

Economic disputes resulting from tourism development have caused the villagers to have a clear understanding about the extent of power of the traditional cultural elites. "We have no choice but to strive for land, because land is limited yet expensive, and everyone thinks that land is as valuable as his/her life," (Villager A09). All the interviewed villagers think that the imams have no power to intervene in such disputes, which should be governed by the government and laws. In face of such economic disputes, the villagers show common rationality in behavioural selection and they seek a statutory means of settlement that provides an institutional guarantee. Traditional religious rules are not binding in such disputes and the ordinary way of mediation does not appeal to the villagers' selfinterests. The head of the Huihui Village Committee (A10) said clearly, "The imam has no authority, but the village committee has. We can make both parties reach an authoritative deal, or help them resort to the town government and the court, while the imam can only handle disputes orally and informally." An imam (A06) said helplessly, "I did persuade them, but it was up to them to follow it or not, and I could only reason with them." The Hui religious elites can only rely on the traditional way of moral education (reasoning), but this has no administrative or legal effect in handling disputes among the villagers.

\section{Elites' enhanced powers external to the community}

In handling land disputes, arising from tourism development, between the communities and the government and developers, the powers of the religious elites in Hui villages have been enhanced.

In the morning of August 17, 2012, a mass event occurred in Huixin Village. On the Huixin Village Balian Road segment of Jiefang Road in Sanya, the villagers fought with the workers of Meihaoli Development Company on the construction site. The conflict arose from a dispute over a plot of over $700 \mathrm{mu}$ (46.67 ha) on which the company was doing some construction. This plot had been leased by non-local farmers several decades ago and it had been transferred to the company. In 2010, the company planned to develop the Golden Bay project here, resulting in grievance from the villagers in Huixin Village. After the failure of many mutual negotiations, the Sanya Municipal Government and the Fenghuang Town Government established a task force together with the public 
security authority, in which over 10 religious elites represented the Huixin villagers, in an attempt to resolve the issue with the government and the developer. The religious elites were chosen because the villagers believed that they acted fairly and were capable of negotiating with the company, while the government thought that the mosque was a creditable and effective medium for communicating with the villagers. It was anticipated to be a win-win situation among the parties.

The head of the Nankai Mosque Management Committee (A03) described the negotiation process as follows, "After the event, the mosque told the villagers that they should not fight, and then talked to the company. The company initially proposed to pay an indemnity of RMB 15 million (USD 2.3 million, INR 30 million), but we disagreed with it. Later, the company proposed to pay RMB 30 million (USD 4.5 million, INR 307 million) and showed us a relevant official document, but the villagers did not accept it. We persuaded the villagers one by one, explained relevant legal provisions to them, and then negotiated with the company and the government. Finally, it was agreed that RMB 10,000 (USD 1,500, INR 102,000 ) was to be paid to each villager (about 4,000 villagers in total)." The total indemnity was RMB 40 million (USD 6 million, INR 408 million). This negotiation process underwent three stages and the negotiation results of each stage were disclosed to the villagers at the worship sessions. Both the parties finally entered into a contract at Nankai Mosque. In this event, the role of the religious elites in coordinating with an external interest group on behalf of the community was given full play.

The ability of the religious elites in the Hui villages in Sanya to integrate the interests of the community with external groups in a traditional sense has continued. When a conflict of interest arises, the elites have the trust of both the sides by serving as mediators. The religious elites have a dual voice for both the community residents and the external interest groups, and their powers have been enhanced through continuing conflicts that require mediation.

In such events, the traditional cultural elites practice reasoning and persuasion internally, and use personal wisdom to strive for reasonable interests externally. The exercise of such influence of powers has been recognized jointly by the villagers, the external interest groups, and the government. With the involvement of the government and companies in local tourism development, their conflicts with Hui villages are increasingly frequent. They need capable, prestigious community agents to assist them in managing the communities and handling disputes; the villagers also need fair, well-educated authorities to speak for the 
communities and strive for interests. The in-service imams in the Hui villages have all-around competencies and social capital. On one hand, they are well-educated, and most of them (four out of six) have the experience of studying abroad (see Table 1). On the other, most of them are from well-off families, deal with tourism operations, and have strong social relations. Their personal competencies and social capital make them ideal mediators for the villagers and the government.

Table 1: Profiles of In-service Imams in Hui Communities

\begin{tabular}{|l|l|l|l|l|}
\hline Mosque & Surname & Age & $\begin{array}{l}\text { Educational } \\
\text { background }\end{array}$ & $\begin{array}{l}\text { Years of } \\
\text { service }\end{array}$ \\
\hline Nankai & $\mathrm{Pu}$ & 44 & $\begin{array}{l}\text { Studied in Saudi } \\
\text { Arabia }\end{array}$ & 4 \\
\hline Huixin South & Yang & 38 & $\begin{array}{l}\text { Studied in Saudi } \\
\text { Arabia }\end{array}$ & 1 \\
\hline Islamic East & $\mathrm{Hai}$ & 32 & Studied in Thailand & 3 \\
\hline Islamic North & $\mathrm{Pu}$ & 29 & Studied in Gansu & 3 \\
\hline Islamic West & $\mathrm{Li}$ & 30 & Studied in Kuwait & 7 \\
\hline $\begin{array}{l}\text { Ancient } \\
\text { mosque }\end{array}$ & $\mathrm{Lin}$ & 30 & Studied in Henan & 4 \\
\hline Average & N.A. & $\mathbf{3 3 . 8}$ & N.A. & $\mathbf{3 . 6}$ \\
\hline
\end{tabular}

(Source: Interview information)

\section{Expansion of community tourism decision-making powers}

Currently, the commercial tourism activities in Sanya City are very diversified, from coastal leisure vacationing and tropical sightseeing to minority cultural experiences. The Hui villages in Sanya Municipality have become priorities in ethnic and religious tourism development for their unique Islamic customs. The religious elites have been involved actively in tourism development to expand their decision-making powers in the community tourism development.

As early as 2008, the administrators of the six mosques in Huihui and Huixin Villages proposed to develop the existing Islamic culture squares with stronger ethnic characteristics by adding appropriate cultural facilities. In 2010, the Hui villages were formally included in the ethnic and religious tourism development. Afterwards, all the mosques were rebuilt or expanded accordingly. According to the Nankai Mosque 
Management Committee, while the expansion of the mosque was being planned, they also considered building an international Islamic culture exchange center that integrated the mosque, an Islamic culture museum, Arabic school, and tourist reception facility. The proposal was submitted to the government for approval in early 2014. The mosque management was fully involved from proposal preparation and application to fundraising. In the words of the head of the Nankai Mosque Management Committee (A05), "It is the public that has elected us to these positions. Since they trust us, we should do whatever we can do." The starting point of such power transfer is elevating the status of Islamic culture. "It must be expanded to receive more and more non-local Muslims and should match the Hainan International Tourism Island"; "The Prime Minister of Malaysia and other state leaders have visited here, so we must make others aware of our culture," (Members of the Nankai Mosque Management Committee, A01 and A02).

\section{Foundation of Power for Religious Elites}

Behind the changes in the power of the elites' authority are the sources and foundations of that power, which reflect their skills, resources, and abilities, as well as the extent of change in the social and cultural environment (Yang and Huang, 2011). Weber thinks that legitimate power emanates from authority and proposes three types of authorities: traditional, rational-legal, and charismatic, each of which is conferred by customary and accepted behaviour, rational public rules and institutions, and leaders' personal competencies and charisma, respectively (Turner, 2006).

In the Hui villages in Sanya, management powers of the religious elites in religious affairs have been expanded and enhanced. The sources of such power are mainly the religious rules and cultural customs, namely the type of traditional authority as exposited by Weber. Most existing studies posit that the social foundation of traditional authority in the Chinese villages is community memory and social solidarity. In this view, community memory reflects the level of fusion between the community history and the traditions, and it is mediated through reality and can be enhanced through eulogizing and inheritance. Social solidarity means the capacity for social action formed by interrelations among the villagers (Cui and Wang, 2015). In villages with strong community memory and social solidarity, there are strong traditional morals and ethnic identity, relations 
between the traditional elites and the villagers are close, and there is strong pressure for public conformity, so that the traditional elites can exercise their powers through clan (religious) ethics and public opinion (He, 2000; He and Tong, 2002). The Islamic faith of the Hui villages in Sanya is underpinned by strong community memory and social solidarity, where religious and cultural traditions penetrate deep into the villagers' daily life, including daily diet, dressing, worships, religious education, etc., and even affect their plans for the future (such as studying in Arabic countries). The villagers form strong ethnic connections through religion and culture. Under the regulation of the religious faith, they do not marry non-Muslims, so ethnic endogamy prevails in the two villages, and many villagers have remote or close in-law relations living nearby. The mutual support spirit of Islam has formed a tradition that "anyone in difficulty receives support from everyone".

The development of the local tourism economy has strengthened the community memory and social solidarity to some extent. First, the tourism economy makes the villagers more capable of expressing their own religious awareness, as reflected in the construction and expansion of several mosques, the further Arabization of residential houses, more frequent pilgrimages to the Arabic region, and more generous donations in the two villages in recent years (Sun and Chen, 2012); second, the host-tourist interactions have inspired cultural consciousness and identity (Sun and Chen, 2012), and have drawn greater attention to ethnic and religious image; and finally, tourism has strengthened the connections of non-local Chinese Muslims with the local communities, and has expanded the foundation of religious authority to some extent. These factors have jointly formed a "community of morality" with a strong moral binding force, and have provided a powerful ethical foundation for the exercise of powers by the religious elites.

Due to the religious elites' direct actions in resolving conflicts of interest in tourism, their mediation powers in the Hui villages have become "externally strong yet internally weak". Local land and real estate disputes have confronted the villagers with choices of raw economic interest, where the power of the traditional moral education of the religious elites seems weak. On the other hand, conflicts between the community residents and external interest groups in tourism development have highlighted the importance of interpersonal skills and social capital of the religious elites in their role as community representatives, where the foundation of their powers is no longer religious authority but their personal competencies, that is, deal-making abilities. From the perspective 
of social environment, Fei Xiaotong (2012) proposed distinctions, "elder power" to "current power", when studying a traditional rural society. He thought that when society changes rapidly and the traditional culture is unstable, "current power", that represents personal competencies, replaces "elder power" based on traditions. The entry of tourism-led modernization has broken the closed social state of the Hui communities, which are hence faced with more new issues and challenges. The importance of contractual relations and legal awareness in the market economy has been highlighted, requiring that the religious elites responsible for maintaining village order should not only be "moral judges" who master religious ethics, but be "community representatives", "intermediaries", and "technical experts" with talent and social integration competencies. In addition, as religious culture gradually becomes a tourist attraction of value, the religious elites in the Hui villages are actually increasing their comprehensive social power capital.

\section{Conclusion and Discussion}

It can be seen from the changes in the power of authority of the religious elites in the Hui villages in Sanya that tourism both impacts the traditional society and conserves the cultural traditions. Accordingly, it is useless to discuss whether the social and cultural impacts of tourism on minority communities are unequivocally "positive" or "negative". In addition, tourism development has opened up a new space for the expansion of ethnic religion and culture, and the religious elites have been involved actively in tourism development through their own efforts due to their high educational levels, thereby enhancing their influence. Though the traditional cultural authority in the minority areas is faced with the threat of being weakened under the modernization forces of tourism, the traditional cultural elites can still draw upon their influence of traditional authority in modern public areas. They have adapted to the socio-economic changes, and by integrating their traditional religious affairs closely, their traditions have advanced with the times. This provides an inspiration for how to resolve the conflict between tradition conservation and modernization. Since the Hui communities in Fenghuang Town, Sanya have strong religious faith and ethnic identities, socio-economic changes resulting from tourism have drawn adequate attention from the religious elites, while changes in the power of the 
traditional elites in other minority communities do not necessarily follow this path.

Chinese scholars have always argued over the nature of community governance in development, namely if the homogeneity of village order based on traditional elite governance is antithetic to modern democratic and legal community building. In the case of the Hui villages in Sanya, it is certain that traditional elites still play an active role in maintaining rural order, especially in inheriting and conserving traditional culture. Of course, this does not mean that the development of rural grass-roots society always involves the elites' prerogatives and that elite governance is just a certain transitional stage in socioeconomic development. German philosopher and sociologist Karl Mannheim once pointed out, "Democracy is characterized, not by the absence of all elite strata, but rather by a new mode of elite selection and a new self-interpretation of the elite" (More, 1990). In the present case, the traditional elites are increasingly exhibiting modern market rationality and legal awareness when participating in community governance. This trend clearly shows the direction of rationalization and standardization of elite governance, and in the future, the functions of elite governance should be performed on the basis of legal regulation.

\section{References}

Brohman, J. (1996). 'New directions in tourism for third world development.' Annals of Tourism Research, 23.

Cui, Y. Q., Wang, C. F. (2015). 'Disassemble and integration: Study on the three layers of Rural governance order from the village elite perspective.' Journal of the Party School of Cpc Ningbo Municipal Committee, 4, 95-102.

Cynthia A.C. (1995). 'Crafting selves, the lives of two Mayan women.' Annals of Tourism Research, 22(2).

Fei X. T. (2012). From the Soil (Version 1). Beijing: People's Publishing Press, p. 96-97.

Giddens, A. (2009). Sociology (Version 5). Beijing: Peking University Press, p.721-723.

Grunewald, R.D.A. (2002). 'Tourism and cultural revival.' Annals of Tourism Research, 29. 
He,X.F.(2000). 'The village elite and community memory: two-dimensional framework of understanding the nature of the village.' Social Science Journals, 4, 34-40.

He, X. F., Tong, Z. H. (2002). 'On Social Solidarity of Villages-also on the Social Basis of village Order.' Social Sciences in China, 3, 124-134.

Jin, T. J. (2002). 'Analysis of the Elite in the Township-Level Governance.' QILU JOURNAL, 5,119-125.

Joseph, C.A, Kavoori, A.P. (2001). 'Mediated resistance: Tourism and the Host community.' Annals of Tourism Research, 28(4).

Liao, Y. (2005). 'The Exploitation of Tourist Handicraft and the Ethnic Commercial Culture.' Guizhou Ethnic Studies, 3, 134-141.

Liu, D. P. (2008). 'Study on Employees Engaged Earlier in Rural Community Tourism Industry: Enlightenment from the Case of Yuanyang Hani Terrace.' Tourism Tribune, 8, 45-51.

More, T. (1990). Elites and Society. Hong Kong: Social Theory of Press, p. 96.

Sun, J. X. (2004). 'The Ethnic Identity and Ethnic Relationship in the Background of the Modernization: with an Example of the Hui People in Fenghuang Town of Sanya, Hainan.' Ethno-National Studies, 3, 61-67.

-. (2005). 'Positive Effects of Community Participation in Tourism upon the Protection of Ethnic Traditional Culture.' Journal of GuangXi University for Nationalities (Philosophy and Social Science Edition), 4, 35-39.

Sun, J. X., Chen, H. (2011). 'The impact of tourism on ethnic Relationship for destination community: a case study of Hui Nationality.' Thinking, 6, 25-30.

Sun, J. X., Chen, H. (2012). 'The impact of tourism on ethnic identity for destination community: A case study of Hui Nationality.' Geographical Research, 4, 754-768.

Sun, J. X., Zhang, S. Q. (2015). 'The Social Space Production in Ethnic Tourism Community: a case Study from the Hui Community in Sanya, Hainan.' Ethno-National Studies, 2, 68-77.

Tosun, C. (2000). 'Limits to community participation in the tourism development process in developing countries.' Tourism Management, 21(6), 613-633.

Turner, J. H. (2006). The Emergence of Sociological Theory (Version 1). Tianjin: Tianjin People's Press, p. 180-192. 
Walpole, M. J., Goodwin H. J.(2000). 'Local economic impacts of dragon tourism in Indonesia.' Annals of Tourism Research, 27(3).

Weng, S. X. , Peng, H. (2010). 'The Impact of Power Relationship on Community Participation in Tourism Development-A Case from Furong Village at Nanxi River Basin, Zhejiang Province.' Tourism Tribune, 9, 51-57.

Wu, H. (2006). 'The impact of tourism on cultural changes of ethnic areas.' Economic and Social Development, 5, 170-172.

Wu Q. F. (2007). 'From A Common Villager to Community Elite: A Typical Case of China's Tourism Elite-Taking "Mamamoon" in Yangshuo as A Case.' Tourism Tribune, 7, 87-90.

Yang, Z. Y., Huang, J. R. (2011). 'The connotation of the theory of power, form and measure.' Journal of Guangdong Institute of Public Administration, 4, 35-41.

Zang, D. S. (2011). The production of the rural elite seeking land: study on agricultural change of farmers' land rights. Beijing: Social Sciences Academic Press, 2011.

Zhang, X. M. (2006). 'The impact of management elites 'experience on rural community tourism-a case of X Village in the south of Anhui Province.' China Rural Survey, 1, 30-38.

Zhou, C. F. (2013). 'Rural Tourism and Elite Reproduction-A Case Study of Hui Village.' Journal of Hubei University of Economics, 1, 117-120.

Zhu, X. (2012). 'A Research on the Forming and Acting Mechanism of New Rural Economic Elites in Rural Tourism: Based on a Case Study of Tiger Leaping George Hiking Route in Yunnan, China.' Tourism Tribune, 6, 73-78. 